Довгалець Ю. В., старший викладач (Національний університет водного господарства та природокористування, м. Рівне)

\title{
ПРИНЦИПИ УПРАВЛІНСЬКОГО ОБЛІКУ В ІСТОРИЧНОМУ АСПЕКТІ
}

\section{Стаття присвячена розкриттю принципів управлінського обліку в історичному аспекті свого розвитку. Розкрито ефективність конт- ролю затрат.}

Ключові слова: принципи управлінського обліку, Міжнародна федерація бухгалтерів, затрати, фінансовий облік, управлінський облік.

У процесі еволюції виробничого обліку і калькулювання сформувалися визначені загальнометодологічні конструкції управлінського обліку. Головна з них полягає в тім, що управлінський облік організований на основі загальних принципів виходячи з технологічних і організаційних особливостей конкретного підприємства, внутрішніх потреб керування, його цілей і задач. Самі загальні принципи полягають у тому, щоб, ґрунтуючись на логіку, досвіді і загальній прийнятності забезпечити керівництво корисною інформацією. Далі, оскільки управлінський облік $є$ обліком внутрішніх потреб і служить інтересам підприємства, він не регламентується державою. Тим часом, принципи і методи управлінського обліку розробляються і національними, і міжнародними організаціями професійних бухгалтерів.

Приміром, у п'ятьох главах третього титулу французького Національного плану рахунків (PCG), розробленого Національною радою по бухгалтерському обліку, здійснене докладне методичне пророблення проблем організації управлінського обліку. Так, глава А присвячена понятійному апаратові (розкриває такі облікові категорії, як управлінський облік, ціни, продукція, витрати, витрати), а також визначає мети управлінського обліку. У ній викладена процедура добору витрат для аналізу в залежності від видів діяльності підприємства, показаний взаємозв'язок управлінського і фінансового обліку. У главі В описані концептуальні основи і сфера застосування економічного аналізу, дана функціональна класифікація центрів витрат. Глава 3 містять рекомендації з використанню рахунків IX класу, призначених для управлінського обліку. Глава D розкриває підходи до виділення видів діяльності, виявленню центрів прибутку і визначенню собівартості, облікові запасів. У ній показані розходження обліку витрат у фінансовому й управлінському обліку, порядок коректування витрат у зв'язку з відхиленнями фактичних показників від нормати- 
вних. У главі Е проілюстрований механізм контрольних функцій управлінського обліку, його роль у прийнятті рішень. Викладено концептуальні підходи до виділення різних типів витрат, до обліку на основі стандартних витрат, бюджетуванню. Звідси випливає, що для Франції характерний значний рівень стандартизації в системі управлінського обліку.

Одна з найбільш авторитетних у світі організацій професійних бухгалтерів - Міжнародна федерація бухгалтерів (IFAC). П̈і Комітет 3 фінансового й управлінського обліку уповноважений IFAC розробляти і видавати матеріали з проблем управлінського обліку. До дійсного часу Комітетом розроблена і видана система нормативів по практиці міжнародного управлінського обліку і ряд нормативів по дослідженнях у його області. Вони містять рекомендації щодо методів і прийомів управлінського обліку.

Ефективність контролю затрат залежить від власне самого контролю і заходів, що приймаються керівництвом фірми для покращення якості управління підприємством. Звіти за результатами обліку і контролю затрат направляються на три рівні управління: адміністративний (вищий), по підрозділах (середній) і виробничий (нижчий). Кожен рівень потребує інформації для визначення і рішення проблем, що виникають в процесі діяльності підприємства. Причому, інформація, яка допомагає вирішувати одні проблеми може бути зовсім не прийнятною для рішення інших проблем. Наприклад дані, зібрані для вимірювання затрат та складання звітності по виробничим затратам минулого періоду, часто бувають неприйнятними для прийняття рішень по обсягу випуску і майбутнім цінам на адміністративному рівні.

При цьому важливо зазначити, що на першому етапі облік був лише засобом реєстрації господарських операцій за допомогою методу подвійного запису і складання фінансової звітності. За допомогою виробничого обліку, як частини бухгалтерського, здійснювалось виключно узагальнення затрат для калькуляції собівартості продукцїі.

На етапі виробничого обліку, який перестав задовольняти потреби управління в умовах конкуренції, ускладнення технології та організації виробництва, була посилена контрольна функція обліку 3 використанням систем калькулювання стандартних затрат і оперативного аналізу відхилень. Формування управлінського обліку, як окремої галузі теоретичних і практичних знань, пов'язано з розробкою системи калькулювання змінних затрат (директ-кост) і обліку затрат за центрами відповідальності. Внаслідок впровадження цих 
систем сформувалась окрема підсистема бухгалтерського обліку, яка використовувала не лише грошові вимірники і була зорієнтована не на потреби калькулювання продукції для складання офіційної звітності, а на прийняття поточних управлінських рішень та в майбутнє. Отже, можна вважати, що управлінський облік, як самостійна система, сформувалась усередині XX ст. Саме в цей період управлінський облік став обов'язковим навчальним курсом для менеджерів в університетах США, а з часом поширився і на інші країни в інших континентах. Четвертий етап еволюції управлінського обліку розпочався в 70- роках та пов'язаний з посиленням ролі стратегічного управління.

Виділення управлінського обліку із загальної системи обліку у міжнародній практиці бухгалтерського обліку пов'язано з проблемами підвищення ефективності підприємницької діяльності.

Сучасний управлінський облік використовує не лише внутрішню, але і зовнішню інформацію, не лише фінансові, але і не фінансові показники, забезпечує потреби не лише виробництва, а й маркетингу і інших функцій бізнесу. За допомогою управлінського обліку здійснюється контроль і аналіз не лише поточних, але і довгострокових цілей. Управлінський облік забезпечує ефективність управлінської діяльності підприємств, їх конкурентоздатність і положення на ринку. Фінансовий облік, як частина інформаційної системи підприємства (в силу своєї специфіки) не здатний забезпечити управлінців необхідною інформацією 3 метою прийняття управлінських рішень. Крім того, управлінські рішення ґрунтуються на плановій, нормативній, технологічній, технічній, аналітичній і інших видах інформації, яку і залучає управлінський облік з метою підготовки конкретної інформації для задоволення потреб управлінців.

Першою розробкою, що стосувалась проблеми управлінського обліку на основі досвіду розвинутих країн, виданою у 1986 році у Польщі, а у нас в країні в 1991 році, була монографія польського професора А. Яругової. Професор Я. В. Соколов охарактеризував їі наступним чином: дуже чітко показано, як на перший план в діяльності бухгалтера висуваються управлінські завдання, що потребують для свого рішення використання розвинутого математичного апарату і сучасної обчислювальної техніки. Це уже принципово нова бухгалтерія і більшість із їі змісту дуже швидко увійде в практику нашої економічної і бухгалтерської роботи [7, С. 67].

Концепції управлінського обліку закріплені міжнародними нормативами фінансового і управлінського обліку у лютому 1989 року. Нормативи видані Комітетом управлінського і фінансового обліку Міжнародної Федерації бухгалтерів з метою сприяння розвитку і використанню управлінського обліку у практиці різних країн. 
Отже, виникнення системи управлінського обліку слід розцінювати як об'єктивну необхідність сучасного періоду, яка покликана вирішити завдання, пов'язані з новою економічною ситуацією (конкуренцією на внутрішніх і зовнішніх ринках, розвитком зовнішньоекономічних зв'язків, використанням АСУ, прискореним розвитком технологій, автоматизацією виробничих процесів, необхідністю розробки нових методів управління), які не можливо вирішити на основі існуючої вітчизняної системи бухгалтерського обліку.

Намагання систематизувати теоретичні розробки і практичний досвід відносно виникнення і розвитку системи управлінського обліку привели нас до висновку, що еволюція управлінського обліку тісно пов'язана з історією розвитку системи управління підприємств і їх структурних підрозділів.

Деякі автори виникнення управлінського обліку також пов'язують з появою внутрішньо фірмових правових і економічних відносин. Так, Т. Джонсон і Р. Каплан в американському напряму у становленні та розвитку управлінського обліку виділяють такі основні етапи: Середина XIX ст. - розвиток залізничних доріг і морських сполучень різко розширює межі комерційної діяльності, а це потребує складання перспективних прогнозних розрахунків, обчислення собівартості послуг, товарів, їх транспортування. Остання третина XIX ст. - виникнення двох паралельних і взаємодоповнюючих одна одну систем фінансового і управлінського обліку. Остання чверть XIX ст. - Тейлором створюється система виробничого нормування, яка привела до формування принципів стандарт-кост, широко використовуються оціночні величини як то прибуток на інвестований капітал [5].

Отже, поглянемо на становлення та розвиток управлінського обліку з точки зору системи управління підприємств. І етап пов'язаний з розвитком промислових підприємств текстильної промисловості у Західній Європі, що розпочався у кінці XУІІІ ст. та був пов'язаний з централізацією і концентрацією виробничих процесів. При цьому менеджери, в руках яких сконцентрувалась велика кількість виконавців, оволоділи потужним важелем контролю за роботою дрібних виробників. Отримавши практично ніким не обмежувану владу над виробничою діяльністю, менеджери могли особисто впливати на динаміку найважливіших показників - собівартість та продуктивність праці, а отже і фінансові результати.

Однак з часом вони зітнулись з проблемою, яка містилась у тому, що інформація, яка необхідна для оцінки затрат, що раніше забезпечувалась та гарантувалась ринковими цінами у формі ціниставки на 1 од. товару, перестала виконувати свою роль. Це вимага- 
ло уточнення затрат за операціями, що відбувались на самому підприємстві. Пошуки шляхів вирішення цієї проблеми привели до використання для цих цілей системи рахунків та подвійного запису, що давало вичерпні дані про використання матеріальних, трудових і інших затрат кожним робітником, на 1 од. випуску та кожним процесом окремо. За словами Х. Джонсона цей тип облікової системи «послужив основою для формування виробничого обліку зі спрощеними формами організації управління» [6, С. 141].

Інформація про витрати наштовхнула виробників на пошук інших шляхів удосконалення виробничого процесу, подальший економічний розвиток яких вплинув на еволюцію існуючих систем обліку затрат.

Наступний етап розвитку управлінського обліку пов'язаний 3 появою нових вимірників на залізничному транспорті (витрати на 1 т/ км, на 1 пасажиро/км і процентне співвідношення доходів і витрат), що пов'язано було з появою залізничних доріг. У цей же час в роздрібній торгівлі почав використовуватись показник величини прибутку і запасів у процентному відношенні до продуктивності праці різноманітних дільниць. Саме у цей період виникла необхідність в існуванні системи, яка б характеризувала динаміку поточних виробничих процесів, а не кінцевих результатів, якими більше цікавились акціонери і кредитори підприємства. Це пов'язано було з тим, що більша увага стала зосереджуватись на процесах виробництва. Отже, ще раз підтвердилось те, що власників та керівників підприємства (менеджерів) цікавила різна інформація. Менеджери проявляли інтерес до доходів з точки зору їх збільшення за рахунок зменшення затрат, які могли мати місце у поточній виробничій діяльності, тому і увага їх була до використання таких методів обліку, які б давали можливість впливати на динаміку поточних виробничих ресурсів з метою їх скорочення. Власників же більше цікавив кінцевий результат діяльності підприємства та розміри дивідендів на вкладені кошти.

Саме у цей період почалось пряме розмежування облікової інформації на зовнішню (фінансову) і внутрішню (управлінську), а дві системи продовжили свій подальший розвиток практично незалежно одна від одної у різних напрямах з різними завданнями та цілями.

Наступний етап розвитку системи управлінського обліку пов'язаний з появою підприємств-гігантів у другій половині XIX ст. При цьому виникло декілька проблем, які покликана була вирішити система управлінського обліку. По-перше, підвищення ефективності виробництва, по-друге, координація роботи в окремих структурах підприємства, що пов'язано було зі здійсненням контролю за постачанням сировиною і матеріалами, за використанням сировини у про- 
цесі виробництва і нормуванням. Вирішення приведених проблем, що виникли на даному етапі, вимагали відповіді від системи обліку. У цей період в розвиток системи обліку значний внесок здійснили інженерні робітники, які направили свої зусилля на підвищення ефективності виробничих процесів та стандартизацію операцій. При цьому стандарти контролю якості матеріальних і трудових затрат будувались на визначенні найраціональнішого шляху здійснення операцій. Це привело до створення нової системи «стандарт-кост», та її використання з кінця XУІІІ ст. Інженерна думка, яка головним чином була направлена на підвищення продуктивності праці і ефективності виробничих процесів за допомогою різноманітних технічних коефіцієнтів, панувала в обліку близько двох десятиріч.

Отже, виникнення управлінського обліку зобов'язане проблемам, що почали виникати в індустріальному виробництві та було направлене до системи Тейлора, обліку витрат за методом «стандарткост», бюджетуванню і системі гнучких кошторисів, методу «директкост». Управлінський облік розвивався паралельно з ускладненням виробничих процесів, виходячи із життєво важливих потреб внутрішнього управління і склався у сучасну систему вкінці 40-х років XX ст.

Наступний етап в розвитку системи обліку i, зокрема, управлінського розпочався згідно одних джерел перед ІІ Світовою війною, згідно інших джерел - після ІІ Світової війни. Цей етап був пов'язаний з подальшою спеціалізацією виробничих процесів, що проявились у виникненні корпорацій на території Америки та Західної $\Theta_{\text {в- }}$ ропи. Створені корпорації мали у своєму складі філії, що займались виробництвом продукції у різних галузях економіки та розміщені були на різних територіях. Це сприяло виникненню нового виду контролю - за групами підприємств [7, С. 265].

При цьому система управління зустрілись 3 новими проблемами, що містились у пошуку шляхів збільшення доходів на капітал, вкладений в об'єднані корпорації. Система обліку повинна була відповідати новим економічним умовам, для цього їй слід було відповісти на основне питання, а саме: як раціонально розмістити засоби підприємства між підрозділами пропорційно доходам на вкладений капітал? На це питання могла дати відповідь система управлінського обліку з використанням методу «директ-кост». Це був початок виникнення стратегічного управління. При цьому стратегічна роль управлінського обліку містилась у координації діяльності всіх підрозділів, пов'язаних з поточними змінами у різноманітних сферах діяльності та була спрямована в сторону сприяння розробки загальної стратегії і прийняття рішень відносно найбільш прибуткового розміщення ка- 
піталу. Одночасно почала розвиватись система бюджетного планування і контролю, яка покликана була поєднати окремі напрями діяльності різних підрозділів зі стратегічними напрямами діяльності всієї організації. Тобто ці дві системи пов'язали кожен підрозділ підприємств-гігантів із загальними цілями організації. Найбільш повне розкриття внутрішньої інформації при використанні указаних систем досягалось за допомогою показників, що дозволяли одночасно оцінити діяльність підрозділів і підприємства у цілому. Прикладом таких показників стали:повні затрати підприємства (підрозділу) на виробництво продукції (робіт, послуг);сукупний дохід з інвестованого капіталу.

Зазначені показники були використані підприємствамигігантами для оцінки ефективності використання капіталу і для більш доцільного розподілу капіталу по прибутковим підрозділам. Компанії Дюпон і Дженерал Моторс, які у результаті упровадження цих двох систем домоглися взаємозв'язку кожного підрозділу із загальними цілями організації, отримали набагато кращий сукупний дохід з капіталу ніж окремі фірми, які не використовували ці системи.

Подальший розвиток системи управлінського обліку на підприємствах був пов'язаний з децентралізацією відповідальності, виникненням центрів відповідальності, центрів прибутку та центрів інвестицій. При цьому відповідальність за організацію поточної діяльності делегувалась менеджерам підрозділів, а вище керівництво підприємства концентрувало свою увагу на координації та оцінці діяльності підрозділів. Саме в цей період система управлінського обліку, що продовжувала розвиватись, почала включати крім обліку виробничих затрат, також планування, бюджетування, контроль, регулювання і стимулювання внутрішньої діяльності підприємств.

Використання бюджетів відіграє важливу роль у процесі управлінського контролю. Постійне порівняння та контроль бюджетних даних з фактичними не лише забезпечує кількісне вимірювання відхилень, але і досліджує причини цих відхилень.

1. Бородкін О. С. Внутрігосподарський (управлінський) облік: концепція і організація. Бухгалтерський облік і аудит. 2001. № 2. С. 45-53. 2. Валуев Б. И. Проблемы развития учета в промышленности. Москва : Финансы и статистика, 1984. 215 с. 3. Вахрушина М. А. Бухгалтерский управленческий учёт : учеб. пособ. для вузов. Москва: Финстатинформ, 1999. 359 с. 4. Кужельний М. В., Лінник В. Г. Теорія бухгалтерського обліку : підручник. Київ : КНЕУ, 2001. 334 с. 5. Нападовська Л. В. Внутрігосподарський контроль в ринковій економіці : монографія. Дніпропетровськ : Наука і освіта, 2000. 224 с. 6. Організація бухгалтерського обліку, контролю і аналізу : підручник / 
А. М. Кузьмінський, В. В. Сопко, В. П. Завгородній ; за ред. А. М. Кузьмінського. Київ : Вища школа, 1993. 223 с. 7. Соколов Я. В. Бухгалтерский учет: от истоков до наших дней : учеб. пособие для студ. экон. спец. вузов. Москва : Аудит, ЮНИТИ, 1996. 638 с. 8. Чумаченко Н. Г. Учет и анализ в промышленном производстве США. Москва : Финансы, 1971. 237 c.

\section{REFERENCES:}

1. Borodkin 0. S. Vnutrihospodarskyi (upravlinskyi) oblik: kontseptsiia i orhanizatsiia. Bukhhalterskyi oblik i audyt. 2001. № 2. S. 45-53. 2. Valuev B. I. Problemy razvitiia ucheta $v$ promyshlennosti. Moskva : Finansy i statistika, 1984. 215 s. 3. Vakhrushina M. A. Bukhhalterskii upravlencheskii uchet : ucheb. posob. dlia vuzov. Moskva : Finstatinform, 1999. 359 s. 4. Kuzhelnyi M. V., Linnyk V. H. Teoriia bukhhalterskoho obliku : pidruchnyk. Kyiv : KNEU, 2001. 334 s. 5. Napadovska L. V. Vnutrihospodarskyi kontrol v rynkovii ekonomitsi : monohrafiia. Dnipropetrovsk : Nauka i osvita, 2000. 224 s. 6. Orhanizatsiia bukhhalterskoho obliku, kontroliu i analizu : pidruchnyk / A. M. Kuzminskyi, V. V. Sopko, V. P. Zavhorodnii ; za red. A. M. Kuzminskoho. Kyiv : Vyshcha shkola, 1993. 223 s. 7. Sokolov Ya. V. Bukhhalterskii uchet: ot istokov do nashikh dnei : ucheb. posobie dlia stud. ekon. spets. vuzov. Moskva : Audit, YuNITI, 1996. 638 s. 8. Chumachenko N. H. Uchet i analiz v promyshlennom proizvodstve SShA. Moskva : Finansy, 1971. 237 s.

Рецензент: к.е.н., доцент Позняковська Н. М. (НУВГП)

Dovhalets Y. V., Senior Lecturer (National University of Water and Environmental Engineering, Rivne)

\section{PRINCIPLES OF MANAGING ACCOUNT IN THE HISTORICAL ASPECTS}

In the process of evolution of production records and calculations, certain general methodological constructions of managerial accounting were formed. The main of them is that the management accounting is organized on the basis of general principles based on the technological and organizational characteristics of a particular enterprise, internal management needs, its goals and objectives. The most general principles are to provide guidance, based on logic, experience and general acceptance, to guide useful information. Further, since management accounting is an accounting for internal needs and serves the interests of the enterprise, it is not regulated by the state. Meanwhile, the principles and methods of managerial 
accounting are developed by both national and international organizations of professional accountants. One of the most reputable organizations in the world of professional accountants is the International Federation of Accountants (IFAC). Its Financial and Management Accounting Committee is mandated by IFAC to develop and publish materials on managerial accounting issues. By the time the Committee developed and issued a system of standards in the practice of international management accounting and a number of standards for research in its field. They contain recommendations on methods and techniques of managerial accounting. The effectiveness of cost control depends on the control itself and the measures taken by the firm's management to improve the quality of enterprise management. Reports on accounting and cost control are sent to three levels of management: administrative (higher), subdivisions (average) and production (lower). Each level needs information to identify and solve problems that arise in the process of enterprise activity. Moreover, information that helps solve some problems may be completely inappropriate for solving other problems. For example, data collected for measuring costs and reporting on past production costs are often inappropriate for making decisions on volume issues and future prices at the administrative level.

Keywords: principles of management accounting, International Federation of Accountants, costs, financial accounting, management accounting.

Довгалец Ю. В., старший преподователь (Национальный университет водного хозяйства и природопользования, г. Ровно)

ПРИНЦИПЫ УПРАВЛЕНЧЕСКОГО УЧЕТА В ИСТОРИЧЕСКОМ АСПЕКТЕ

Статья посвящена раскрытию принципов управленческого учета в историческом аспекте своего развития. Раскрыто эффективность контроля затрат.

Ключевые слова: принципы управленческого учета, Международная федерация бухгалтеров, затраты, финансовый учет, управленческий учет. 